\title{
THE INFLUENCE OF BIOMASS CULTIVATION TECHNOLOGY (SELECTED TYPES) ON THE SELECTION OF MACHINES FOR ITS HARVEST
}

\author{
Zbyszek ZBYTEK, Florian ADAMCZYK, Tadeusz PAWLOWSKI \\ Przemysłowy Instytut Maszyn Rolniczych/ Industrial Institute of Agricultural Engineering, POLAND \\ E-mail of corresponding author: adamczyk@pimr.poznan.pl
}

Keywords: sustainable agriculture, biomass, harvesting technology, machines selection, harvest

\begin{abstract}
The selection of machines and their mode of operation in a given biomass technology depends on the plant species. The date and multiplicity of harvest also depend on the species of the plant and its destination. Under national conditions, energy crops are harvested in late autumn and winter when the plants are in a state of rest and have a resting vegetation. The aim of the study was to analyze the selection of biomass harvesting machines depending on the technology of growing plants belonging to solid biomass. Basic criteria were identified, which included the selection of machines for harvesting certain types of solid biomass. The selection of machines for different technologies of solid biomass harvest is made taking into account their division into groups gathering similar plants. Within the framework of the work, a flowchart of the selection of technical means for the applied technology of solid biomass collection was prepared taking into account the above division and the principles of sustainable agriculture.
\end{abstract}

\section{INTRODUCTION}

Machine selection and the way they are exploited in certain technology of energetic plants harvesting depend on plant species. The term and multiplicity of harvest also depend on plant species and on its purpose. It is one of the rules of sustainable agriculture. Under national conditions, plants designed for energetic purposes are harvested in late autumn and winter period, when the plants are in state of rest and their vegetation is stopped. In the period of the year appears bad weather conditions, the soil has a high moisture content, sometimes there is snow cover. For these reasons it would be advisable, that machines used in certain harvesting technologies were equipped with caterpillar track systems or wide tires.

Selection of machines for different technologies of plants harvesting was made according to divide into three groups:

- trees and bushes, including tree branches,

- grass

- perennials.

\section{BASIC RULES OF HARVESTING MACHINES COMPLETATION}

With consistent with the principles of sustainable agriculture choice of machine for biomass harvesting for energetic purpose, it is very important to consider a biomass production volume and owned tractor. Choice of machines and tractors should provide to accomplish the harvest of plants for energetic purpose in the most gainful term and short time. Then the number of tractors and the groups machines efficiency shouldn't be to large due to over-investment farm over the facility of it accumulation (Muzalewski 2008). In case of using tractor it's recommended to consider the tractor maximal power, which will be cooperate with biomass harvesting machines. Machines should be assort in the way which allow to used $70 \%$ to $85 \%$ nominal power of engine and about $80 \%$ of 
engine load during the work of tractor. The parameters allow achieved the lowest fuel consumption by tractor. Purchase the machine should to contribute to improve production organization, keeping agro technological harvest terms and work safety regulations.

Assorting machines for solid biomass for energy purposes, the worker should consider (Muzalewski, 2015; Zbytek and Adamczyk, 2017):

- acreage,

- farm level of advancement and economic potential,

- way of mechanization of harvesting,

- environment factor,

- topographical factor,

- economic factor.

The basic parameter which define need of machine application is exploitation efficiency - ability to accomplish define work during the day in farm condition. Exploitation efficiency $\mathrm{W}_{07}$ is equal to (1):

$$
W_{07}=\frac{k \cdot A \cdot T}{T_{h}}\left(h a \cdot \text { hour }^{-1}\right)
$$

where:

$$
\begin{aligned}
& \text { A - area of cultivation for harvest (ha } \text { year) } \\
& \mathrm{T}-\text { recommended time of machine exploitation }(20-25 \text { years) } \\
& \mathrm{T}_{\mathrm{h}}-\text { machine exploitation potential in define time (hours) } \\
& \mathrm{k}-\text { correction factor }(0,5-0,75) .
\end{aligned}
$$

In many cases, solid biomass harvesting is making with machines from other plants harvesting technologies. Often there is basic equipment in farms. However sometimes, biomass harvesting is making by using specified machines, which are destined to harvesting only one group of plants. These are machines which are used not so often during the year, functional and construction differentiation is typical for them. In the case these are the most expensive machines, so decision of using them should be preceded by rigorous analysis about efficiency in work on farm, provision of services and collective machine exploitation.

The criterion of minimal exploitation $W_{R}^{N}$, which is using for rating purchase and exploitation is equal to (2):

$$
W_{R}^{N}=\frac{k \cdot T_{H}}{T}\left(\text { hour } \cdot \text { year }^{-1}\right)
$$

Where the symbols have the same meaning as in the equation (1)

It is alleged that purchase of the machine is worthwhile, when $\mathrm{W}_{\mathrm{R}}$ exploitation is $20 \%$ lower than minimal machine exploitation per year in accordance with $W_{R}=0,8 W_{R}^{N}$. 
In many cases planter has to harvest solid biomass for energetic purpose in short agrotechnological term. It is the rough term, which is dependent to weather in a year, soil conditions and vegetation period of cultivated plants. Which means that worker should assess the number of machines for defined biomass harvest area $\mathbf{i}_{\mathbf{m}}$. It can be calculated by (3):

$$
i_{m}=\frac{S}{W_{07} \cdot T_{07} \cdot T_{a}}
$$

Where:

$\mathrm{S}$ - cultivation area (ha)

$\mathrm{T}_{07}$ - shift time (hour)

$\mathrm{T}_{\mathrm{a}}$ - days of agrotechnological term (hour)

To assure continuous work of major machine, worker should select appropriate number of transport devices. Time of machine stop which is an effect of incorrect number of transporting devices in result extend the work time. So, the cost is increasing too. For example, depending on machine constructions and work technology we can divide it for some variants of cooperated work of transport group, harvester or chaff-cutter:

- transport group is moving alongside major machine, material is transported constantly,

- transport device is mounted to major machine,

- machine has its own tank, where material is collected. The trans-shipment take place periodically without stopping machine for loading,

- machine left behind on the ground compacted a briquetted material in shape of poll or filled containers for example sack in big-bag type, which are lading on the transporting vehicles by hay-loader or self-propelled loader.

Many times, user is selecting transporting device for harvesting solid biomass basing on experience or he is using the index method, which is based on adapting criterion (Muzalewski 2015):

- number of transport devices to number of tractors used on farm,

- load of transport devices to drag force of tractors,

- load of transport devices to farm area.

Depending of future cultivation technology, a user selects technical resources.

Coverage which is pertained to select technical resources is showed below:

Type of harvested biomass (plant) $\rightarrow$ estimate of biomass yield $\rightarrow$ owned tractor $\rightarrow$ area of plantation $\rightarrow$ harvest $\rightarrow$ selection of major machine for harvesting $\rightarrow$ loading $\rightarrow$ transport (select of transport resources)

Block diagram which showed selection of technical resources to solid biomass harvesting technology is presented on Figure 1.

\section{HARVEST OF BUSHES INCLUDING TREE BRANCHES}

Short rotation trees and bushes like salix viminalis, populous, robinia pseudoacacia, rosa multifolra are energetic plants. The harvesting takes place when the vegetation period ended and plants are in rest state. Salix viminalis is harvested every two, three or four 
years and populous every five, six or seven years (Towpik 2011). Taking in mind higher and thicker populous sprouts than salix sprouts, for harvesting populous, are used machines which are exploited for timber deciduous and coniferous trees in forestry.

Care of the apple trees orchard is integral with works such as: winter pruning, summer pruning and new seedlings which are generate much waste as cutted of branches. Averagely from 1 ha of apple trees orchard 3,5 Mg waste (branches) is created per year from winter pruning. There must be added about $1,5 \mathrm{Mg} \cdot \mathrm{ha}^{-1}$ wastes from new seedlings (Hetsh 2008; Podlaski, 2010; CIRECE Report, 2013; Dyjakon et al., 2016). Now, that branches are usually raked (manually or with tractor which cooperate with loaders and hay rakes), collected from interrows, gather in prism shape, burn or crumbed by many types of branch grinders or mulchers and throwed around the trees (the action often creates risk of trees illness which has negative influence on future fruit quality). In last years a problem of developing these wastes lays in minds of orchardists and scientists. Nowadays methods of gathering branches, lefts in orchards after pruning, are such as chipping machines mounted to tractors or in limited part pressed by round baler and square baler (Dyjakon et all. 2016).

From the groups plants are collected by single or two-phase method. Characteristically for the single-phase harvest is cutting and crumbing plants at the same time. In this way woodchips are created and transported for transport devices. Two-phase harvest is divided into two independent phases which take place during the work of different machines. During the first phase plants are cutted and left behind as interrows. During second phase, dry plants are crumbed on the field or on the farm.

\section{GRASS HARVEST}

Machines which are used in harvesting green plants are the same as machines in solid biomass harvesting. Harvest of grass for energetic purpose should take place in early spring, when moisture of the harvested plants is the lowest. Fall harvest is possible, but then is necessary to use mowers with conditioner. Mowed material can be gathered by chaff-cutter or square baler, round baler or large size press.

\section{PERENNIALS HARVEST}

Sida hermaphrodita, helianthus tuberosus, reynoutria sachalinensis can be added to the group of plants for energetic purpose. Sida hermaphrodita is cultivated for fodder and biomass purpose, which include bio-gas production. Machines which are used in harvesting perennials and in harvesting green plants and potatoes are the same. 


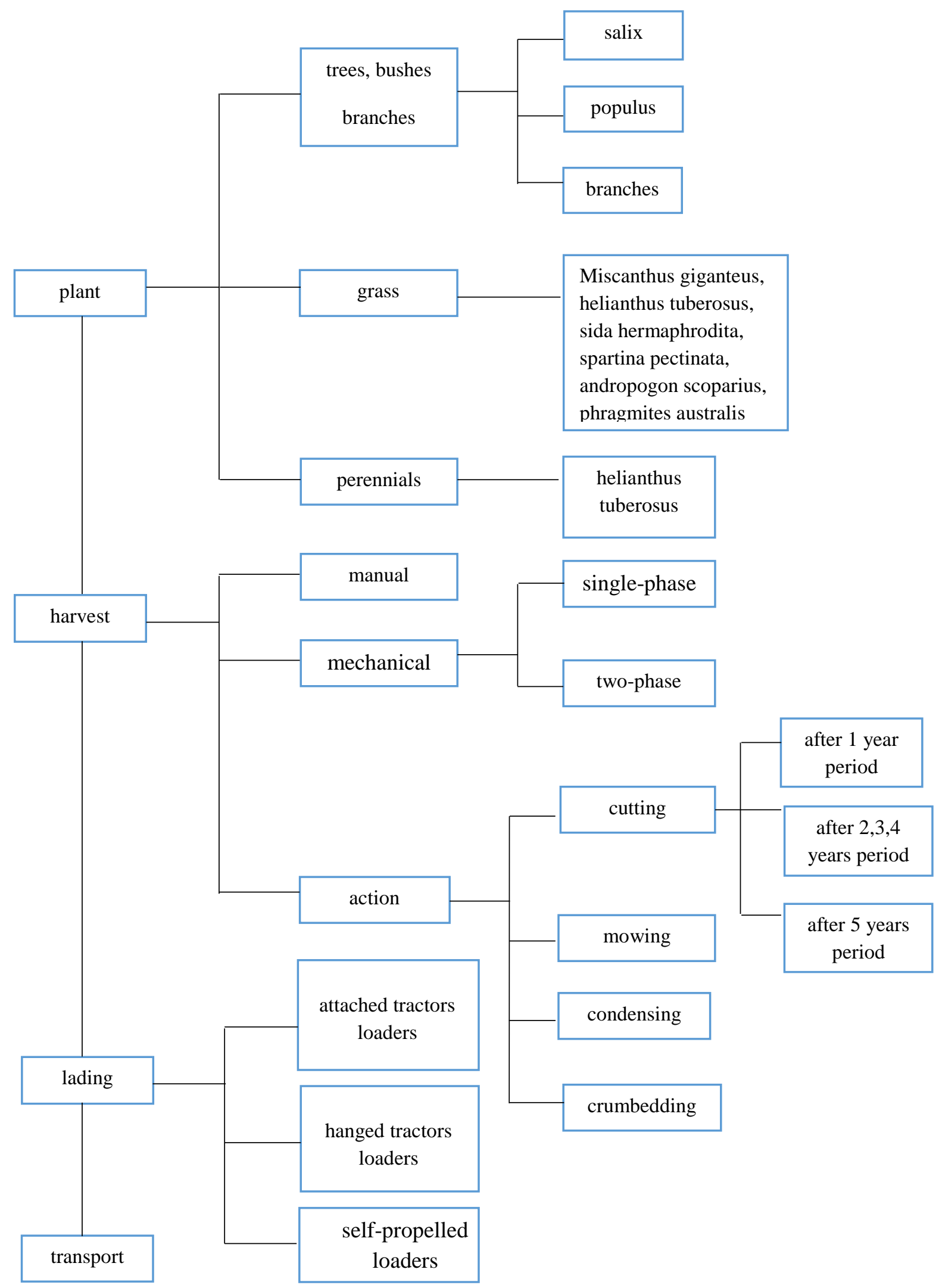

Fig. 1 Block diagram presenting selection of technical resources towards biomass harvest technology (source: own work) 


\section{CONCLUSIONS}

The solid biomass for energy purposes for technical resources selection guidelines were created. Attributes which should be predicted during plantation founding and which are important for technical resources selection were set down. Then, the regulations consistent with the rules of sustainable agriculture of organization of work and transport resources selection were pointed, to provide constant work of major machine. Using division of energetic plants into groups like: trees and bushes, including trees branches, grasses and perennials was create a different type of harvest selection. All these actions are part of the principle of sustainable agriculture and a proper organization of work.

It's been presented an example of how to select the technical means for the collection of solid biomass depending on the crop to be harvested, the technology used, the specificity of the operation as well as the use of the machinery, and the particular technical details to be considered consistent with the rules of sustainable agriculture. A block diagram of the selection of technical means for the applied solid biomass for energy purposes of harvesting technology has been developed, considering the abovementioned division of plants constituting solid biomass.

\section{ACKNOWLEDGMENT}

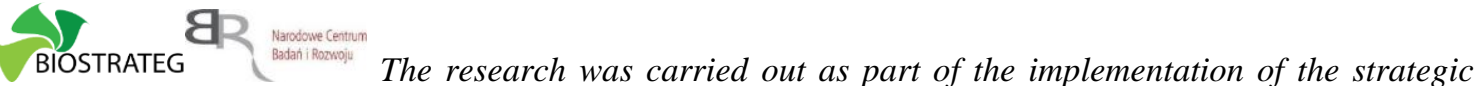
research and development program "Environment, Agriculture and Forestry" - BIOSTRATEG 1, financed by the National Center for Research and Development, BIOSTRATEG 1/269056/NCBR/2015. "Interdisciplinary research into improving energy efficiency and increasing the share of renewable energy sources in the energy balance of Polish agriculture".
}

\section{REFERENCES}

CIRCE Report, (2013). Mapping and analysis of the pruning biomass potential in Europe. Report of EuroPruning - Devenlopment and implementation of new and non-existent lo-gistics chain for biomass from pruning Theme: KBBE.201.1.2-01 [unpublished].

Dyjakon A., den Boer J., Bukowski P., Adamczyk F., Frąckowiak P. (2016). Wooden biomass potential from apple orchards in Poland. Drewno 59 (198), s. 73-86. DOI: 10.12841/wood.1644-3985.162.09

Hetsch S. (2008). Potential Sustainable Wood Supply in Europe. UNECE/FAO Timber Section, October 2008. Geneva:1-34.

Muzalewski A. (2015). Zasady doboru maszyn rolniczych w ramach PROW na lata 2014-2020. Instytut Technologiczno-Przyrodniczy Oddziat w Warszawie, Warszawa.

Muzalewski A. (2008). Opłacalność użytkowania maszyn nabytych z dotacją. Problemy Inżynierii Rolniczej, 3, 27-33.

Podlaski S. (2010) Ocena możliwości pozyskania drewna na cele energetyczne do 2020 roku. Warszawa, Wykonano w ramach projektu: „,Nowoczesne technologie energetycznego wykorzystania biomasy $i$ odpadów biodegradowalnych (BiOB) - konwersja BiOB do energetycznych paliw gazowych” [unpublished].

Towpik T. (2011) Topola zamiast trzciny. RPT nr 3 (145), s.62-63.

Zbytek Z., Adamczyk F. (2017). Możliwości wykorzystania biomasy stałej. Część 2. Sposoby określania potencjału biomasy stałej i doboru maszyn do jej zbioru. Technika rolnicza, ogrodnicza, leśna, nr 3/2017, s. $06-09$. 